\title{
Many Votes, Little Voice: Indonesia's 2019 Presidential and Parliamentary Elections

\author{
Olle Törnquist
}

\begin{abstract}
The recent Indonesian elections signalled relative stability in spite of the rise of contentious politics. To explain this, the article first discusses the way the incumbent Joko "Jokowi" Widodo's administration has handled the rise of Muslim populism sponsored by his political opponents. This has included a reliance on illiberal measures, the political adjustment and "triangulation" of his policies, and a revival of Indonesia's socio-religious and ethnic politics. Second, the article provides a longer historical perspective to show how the failure to restore the liberal parliamentary politics of the $1950 \mathrm{~s}$, and the inability to sustain the popular reforms of the mid-2000s that brought Jokowi to power, constitute more fundamental explanations both for the undermining of Indonesia's democracy and for the provisional political stability.
\end{abstract}

Keywords: Indonesia, elections, democracy, populism, popular politics

DOI: $10.5509 / 2019923459$

$\mathrm{F}$

lor more than three decades, capitalist development under an authoritarian government in Indonesia, Southeast Asia's most strategically situated, populous, and mineral-rich country, seemed to pre-empt democratization. Yet, democratization did eventually come about. Today, however, more than two decades after the fall of the Suharto regime, Indonesian democracy has been dangerously weakened. Most dramatically, in late 2016 and early 2017, President Joko "Jokowi” Widodo's deputy governor of Jakarta, Basuki Tjahaja "Ahok" Purnama, ethnic Chinese and Christian, and with outstanding managerial qualities, lost the elections in which he was widely expected to become full governor. This was the consequence of identity politics and the issuing of a fatwa against him. Jokowi's senior political rivals, including the previous contender in the 2014 presidential race, Prabowo

OLle Törnquist is a professor of politics and development at the University of Oslo. He is the coeditor of Reinventing Social Democratic Development: Insights from Indian and Scandinavian Comparisons (NIAS Press, 2016) and co-author of Dilemmas of Populist Transactionalism: What are the prospects now for popular politics in Indonesia? (PolGov, 2017). E-mail: olle.tornquist@stv.uio.no

Acknowledgement: I am indebted to Professor Gerry van Klinken, University of Amsterdam, for his constructive comments, and to John Harriss for his insightful editing. 
Subianto, a former general and son-in-law of Suharto, as well as the earlier president (2004-2014), General (ret.) Susilo Bambang Yudhoyono, and the Indonesian Ulama Council (MUI), enabled extreme groups to orchestrate a massive campaign and huge rallies against Ahok for blasphemy, and for neglecting socio-economically unprivileged Muslims.

Still, on the $17^{\text {th }}$ of April 2019, it proved possible for the world's largest one-day elections to take place, with 185 million registered voters and 800,000 polling stations. Two pairs of candidates for president and vice president were voted for directly. Some 300,000 candidates vied for more than 20,000 legislative seats in the party-political national parliament and in the 34 provincial and more than $500 \mathrm{regional} /$ municipality councils, and were elected according to the system of proportional representation in multi-member electoral districts. Representatives to the non-party political "senate" were also elected. Five elections in a day. Only the 34 governors, more than 500 heads of regencies and mayors, and more than 75,000 village leaders have separate direct elections. The stiff regulations (to which we shall return) that limit the number of parties that can qualify to participate in the elections certainly hold back political representation of the interests and issues expressed by unions, social movements, and citizen associations. In addition, it takes massive funds to make a difference. And there were conflicts, harassments, and manipulations. Yet, as compared with the other major springtime elections in Thailand and the Philippines, the operation stood out as an exemplar of civil behaviourthough the successful sweeping under the carpet of the major conflicts was not dramatic enough to attract attention in the international media.

Even the outcome was without excitement. Modest local businessman Jokowi, having first captured people's attention around 2005 as one the most honest, understanding, and effective mayors the country had ever had, was certainly hoping for more, but still won with a comfortable margin of 11 percent: 55.5 versus 44.5 percent (as compared with the 6.3 percent margin in 2014: 53.15 versus 46.85$)$. He had been joined by vice-presidential candidate Ma'ruf Amin, the leader of the MUI. The rival pair was, again, led by political strongman and business oligarch Prabowo Subianto. He was partnered with Sandiaga Uno, the deputy mayor of Jakarta, who was a Muslimoriented businessman and financier. In spite of both teams' tendency to soften their stands and not formulate clear programmatic differences (a problem we shall return to), and thus the fear of a low turnout in the elections, turnout actually increased to above 81 percent. The Jokowi-Ma'ruf pairing secured their heartland votes in populous Bali and East and Central Java, together with other provinces with significant numbers of pluralistminded Muslims and non-Muslim voters. The Prabowo-Sandiaga ticket won in the less pluralist Muslim strongholds in the western parts of Java and Sumatra, as well as in South Kalimantan and South and Southeast Sulawesi, West Nusa Tenggara, and North Maluku. Also, while Jokowi won in Jakarta, Prabowo's coalition parties secured the majority in the local council. 


\section{Figure 1}

Presidential elections by province

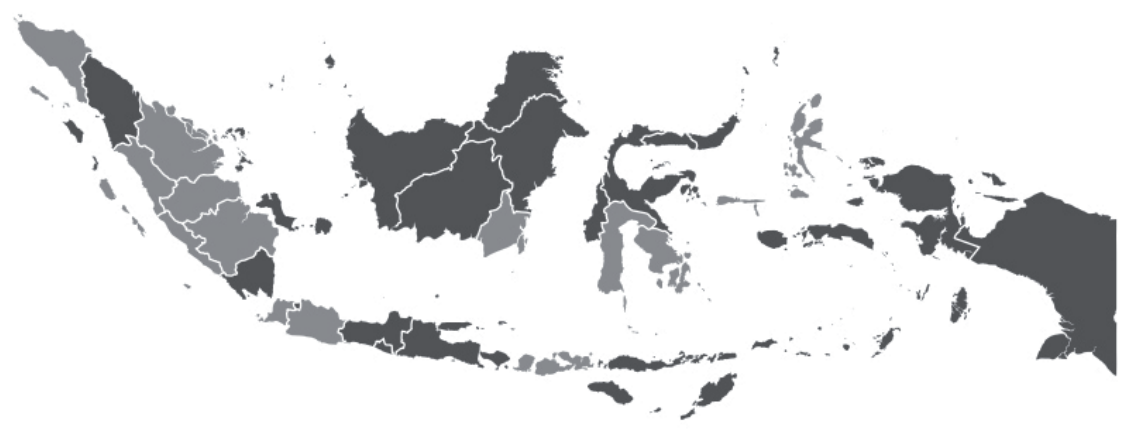

Notes: Dark Grey indicates Jokowi-Ma'ruf; Light Grey Prabowo-Sandiaga.

Source: KPU (General Elections Commission), https://commons.wikimedia.org/wiki/ File:Indonesian_provinces_blank.svg.

Similarly, there were few surprises in the parliamentary elections, as compared with the 2014 elections. Among the parties with a secular orientation, Jokowi's and legendary left-populist President Sukarno's daughter Megawati's Democratic Party of Struggle (PDI-P) gained 19.3 percent of the votes. This was only a little better than in 2014, but the party gained a number of new seats in parliament. The old but now reformed Suharto party, Golkar, that is part of Jokowi's coalition, suffered from divisions and corruption scandals which led to some losses, and its share of the vote decreased from 14.8 to 12.3 percent. Its somewhat less conservative offspring, and member of the same coalition, media tycoon Surya Paloh's Nasdem, did better, increasing its support from 6.7 to 9 percent, and winning several new seats. Among the two nationalist parties that are even more personality driven, and connected with conservative religious groups, Prabowo's own Great Indonesia Movement, Gerindra, made minor increases from roughly 11.8 to 12.6 percent, while former president Yudhoyono's Partai Demokrat supported Prabowo but was sidelined in his coalition and dropped from 10.1 to 7.8 percent. Interestingly, even the explicitly Muslim parties did not make any major gains. Jokowi's ally, the National Awakening Party (PKB), with pluralist inclinations and roots in the traditionalist Nahdlatul Ulama (NU) movement in East and Central Java in particular, made some minor increases from about 9 to 9.7 percent and took several new seats. The less traditionalist United Development Party (PPP), a remnant from Suharto's ambition of bringing Muslims together in one party, and which is now also part of Jokowi's coalition, suffered from a corruption scandal and dropped from about 6.5 to 4.5 percent, losing a number of seats; and the most conservative Crescent Star (PBB) did not even pass the 4 percent threshold. Among Prabowo's allies the National Mandate Party (PAN), with roots in the religiously 
modernist but sometimes less pluralist Muhammadiyah movement, decreased somewhat from 7.6 to 6.8 percent, but the Muslim Brotherhood-oriented Prosperous Justice Party (PKS) increased from 6.7 to 8.2 percent and won several new seats. The pro-authoritarian parties such as Berkarya, led by Suharto's son Tommy in support of Prabowo, and right-wing Perindo and Garuda did not make it to the parliament. Hanura, under Suharto's National Armed Forces commander General Wiranto, more recently Jokowi's coordinating minister for Political, Legal and Security Affairs, suffered badly from internal conflicts and lost out too. The new Solidarity Party (PSI), which tried to mobilize liberal and social democratically inclined progressives among the young urban middle classes, also failed to pass the threshold. Yet it made promising progress in a number of major cities such as Medan, Bandung, Surabaya, Malang, and Denpasar, and most spectacularly won some 9 percent of the vote in Jakarta, gaining more seats than, for example, Golkar. Overall, there were no dramatic changes in the distribution of seats between the two contending alliances (as we see in table 1).

\section{Table 1}

Highlights from the national parliamentary elections in Indonesia, 2019

\begin{tabular}{|c|c|c|c|c|c|}
\hline Party & Coalition & $\%$ Votes & Swing & Seats & Swing \\
\hline PDI-P & Jokowi & 19.33 & +0.38 & 128 & +19 \\
\hline Gerindra & Prabowo & 12.57 & +0.76 & 78 & +5 \\
\hline Golkar & Jokowi & 12.31 & -2.44 & 85 & -6 \\
\hline PKB & Jokowi & 9.69 & +0.65 & 58 & +11 \\
\hline Nasdem & Jokowi & 9.05 & +2.33 & 59 & +23 \\
\hline PKS & Prabowo & 8.21 & +1.42 & 50 & +10 \\
\hline Demokrat & Prabowo & 7.77 & -2.42 & 54 & -7 \\
\hline PAN & Prabowo & 6.84 & -0.75 & 44 & -4 \\
\hline PPP & Jokowi & 4.52 & -2.01 & 19 & -20 \\
\hline Perindo & Jokowi & 2.67 & - & - & - \\
\hline Berkarya & Prabowo & 2.09 & - & - & - \\
\hline PSI & Jokowi & 1.89 & - & - & - \\
\hline Hanura & Jokowi & 1.54 & -3.72 & 0 & -16 \\
\hline PBB & (Jokowi $^{1}$ & 0.79 & -0.67 & - & - \\
\hline Garuda & $(\text { Prabowo })^{2}$ & 0.50 & - & - & - \\
\hline PKPI & Jokowi & 0.22 & -0.69 & - & - \\
\hline
\end{tabular}

Source: KPU (General Elections Commission).

Note: There were 15 more seats in the national parliament in 2019 than in 2014. 
Local parties were only allowed in Aceh. Their importance was further reduced from 42 to 35 percent of the seats in the provincial parliament. This has already caused some of the old combatants in the former Liberatiion movement GAM to contemplate a new quest for a referendum on independence. The conservative GAM-based Partai Aceh lost 11 of their previous 29 seats. The once NGO-based Partai SIRA largely failed to get back into organized politics; and the most progressive Partai Nanggroe Aceh was only able to advance from 3 to 6 seats, perhaps because of its support for Jokowi and for the embarrassing imprisonment for corruption of its leader, the relatively liberal maverick and former head of GAM's intelligence, Governor Irwandi.

As in 2014, the Prabowo team refused to acknowledge either the usually trustworthy quick count results or the real counts by the General Elections Commission (KPU). The authorities welcomed specific complaints, but Prabowo's main point was that there had been massive and systematic fraud. (Massive cheating seems implausible. Jokowi may well have used state funds to boost support, but judging from media reports, Prabowo's use of private money was more extensive.) Most seriously, the Prabowo team initially deemed complaints with the General Election Supervisory Board (Bawaslu) and the Constitutinal Court not to be meaningful, calling their neutrality and probity into question. Rather, the leaders called for "people power" demonstrations, and the police and army were put on high alert in response. The major Muslim organizations Nahdlatul Ulama and Muhammadiyah were reluctant to support the demonstrations, and two of Prabowo's coalition partners (Partai Demokrat and PAN) indicated that they might jump ship in the new national parliament. But in spite of this, on May 21, peaceful and fairly limited demonstrations took place, coinciding with the announcement by the election commission of the results. However, this was followed by two days of riots in Jakarta. Reliable local media provided evidence of the involvement of thugs, brought in by political bosses. Nine people were reported killed and about 700 injured. But while Jokowi is only a moderate Javanese Muslim, he is neither Christian nor of Chinese origin (like Ahok), so identity-based mass mobilization was more difficult than in 2016. The government, moreover, detained two former generals who had connections with Prabowo on the suspicion of treason, and a number of others who were accused of plotting the assassination of some high-ranking government officials and of the former generals and coordinating ministers for Political, Legal and Security Affairs (Wiranto) and Maritime Affairs (Luhut Pandjaitan). So having demonstrated his muscle, and humiliated Jokowi for not being able to preserve peace and harmony, Prabowo called for calm, decided after all to appeal to the Supreme Court, and then put himself onto a private flight, along with Russian friends among others, to the United Arab Emirates

PBB's association with the Jokowi coalition was at a late stage and rather informal.

Garuda's link with the Prabowo coalition was informal. 
and Vienna to attend to his private business and health. Back in Jakarta, Jokowi went out of his way to brief numerous former generals about the developments, and status quo was restored. On June 27, the Constitutional Court closed the case by confirming Jokowi's victory. Prabowo conceded, reluctantly, but extreme Muslims promised a long jihad.

In a comparative perspective, the Jokowi administration has at least managed to remain in power, unlike, for example, the Indian centre-left government that lost out to the Hindu fundamentalists in 2014, the Philippine centre-leftists who were overtaken by Duterte in 2016, and the Brazilian Labour Party that stumbled over corruption and the end of the commodity boom. How can this be explained? I will first discuss the way the Jokowi administration has handled the rise of the Muslim populism sponsored by his political opponents. This has included reliance on illiberal measures, the political adjustment and "triangulation" of his policies, and a revival of Indonesia's socio-religious and ethnic politics. Second, I will provide a longer historical perspective to show how the failure to restore the liberal parliamentary politics of the 1950s, and the inability to sustain the popular reforms of the mid-2000s that had brought Jokowi to power, constitute further and more fundamental explanations both for the undermining of Indonesia's democracy and for the relative stability demonstrated in the 2019 elections.

\section{The Rise of Muslim Populism}

A major cause for what looks like political stability seems to be the way in which Jokowi's team has handled the rise of Muslim right-wing populism. As emphasized by Vedi Hadiz and Richard Robison, ${ }^{3}$ its resurgence (long after the Darul Islam movement of the 1950s in favour of an Islamic state) preceded Prabowo's first presidential campaign in 2014 and the subsequent mobilization against Ahok as governor of Jakarta. Suharto sought to win legitimacy by fostering cooperation between his regime and the socioreligious Muslim organizations, using state patronage. The institution for this was a state-sponsored yet autonomous Indonesian Ulama Council (MUI), which later on gained increasing importance. ${ }^{4}$ During the later period of the New Order regime, Suharto tried to strengthen his position by offering more favours to Muslim groups, most obviously those associated with his successor, Vice President B.J. Habibie and his Association of Muslim Intellectuals (Ikatan Cendekiawan Muslim Se-Indonesia, ICMI). The next president, Abdurrahman Wahid (1999-2001), was the leader of the rival Muslim association Nahdlatul Ulama and of a more pluralistic orientation; but he nevertheless fostered, for example, the practice of sharia law in Aceh.

V. Hadiz and R. Robison, “Competing populisms in post-authoritarian Indonesia," International Political Science Review 38, no. 4 (2016): 488-502.

4 Saskia Schäfer, "Democratic Decline in Indonesia: The Role of Religious Authorities," Pacific Affairs 92, no. 2 (June 2019): 235-255. 
Megawati Sukarnoputri (2001-2004) tried to alter the priorities by containing Muslim privileges. But she soon lost out to General (ret.) Yudhoyono in the 2004 elections. His victory was not least thanks to Muslim support, which he honoured during his two five-year periods in office by accommodating leaders and movements with favourable legislation, institutional support to the MUI, and handouts to Muslim groups and leaders.

Meanwhile, the rise of Jokowi's populist reformism from 2005 onwards (when he became mayor of Solo), turned out to be a game-changer. After reaching the governor's office in Jakarta in 2012, and the presidential palace in 2014, he sought to find a middle course between Megawati's militant defence of pluralist nationalism and Yudhoyono's accommodation of even hard-line Muslims. Jokowi reduced the economic favours offered to them, and liberal and globally oriented leaders such as the Christian and ethnically Chinese Ahok were treated as equal citizens. So Ahok, for one, gained strong popular approval when replacing Jokowi as governor.

These developments caused Muslim social movement leaders and established political elites and oligarchs to come together in an effort to regain their privileges. In the run-up to the 2014 presidential elections and afterwards, Prabowo, his Gerindra party and their main allies, including the Brotherhood PKS party, in addition to the former president Yudhoyono and his Partai Demokrat, as well as the major Muslim organizations Nahdlatul Ulama and Muhammadiyah, and the MUI, joined hands with Muslim extremists such as the Islamic Defenders Front (FPI). The latter gained additional legitimacy by rallying in support of fatwas issued by the MUI. Other extreme Muslim groups followed suit.

Muslim populist politics followed methods similar to those employed by Jokowi, and aimed at fostering direct communication between strong leaders and a supposedly unified "people" against a mutual enemy. Typically, however, Jokowi and Ahok focused on public programs for urban and infrastructural development as well as universal welfare reforms that would be to the benefit of "ordinary people," while their opponents focused on development meant specifically for the Muslim communities. This was in addition to the fatwas issued by the MUI implicating "liberals," Christians, and the ethnic Chinese population. ${ }^{5}$

\section{Maintaining the Status Quo through Illiberalism}

Several scholars trace the relative stability in the 2019 elections to the ways in which the Jokowi team followed up on the massive popular mobilization

See, for example, V. Hadiz, "Indonesia's year of democratic setbacks: towards a new phase of deepening illiberalism?" Bulletin of Indonesian Economic Studies 53, no. 3 (261-278); I. Wilson, "Making Enemies out of friends," New Mandala, 3 November 2016, https://www.newmandala.org/makingenemies-friends/ (Cf. "Democracy, a pathway to hell," New Mandala, 20 March 2014, https://www.

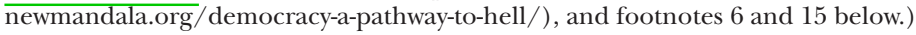


in Jakarta in late 2016. Marcus Mietzner argues convincingly that the administration has combined - in arbitrary, illiberal ways-the three common means of handling right-wing populism around the world: exercise of state authority, accommodating the actors, and accommodating the voters' worries. ${ }^{6}$

More conservative coalition politicians were brought into the presidential staff and cabinet along with several retired generals. This was at the expense of progressives, including those with links to civil society. Jokowi's immediate aim was to counter threats from within the military as well as to foster forceful measures against the militant Muslim groups. Efforts were made, as well, to contain misinformation put out through social media. There were also attempts to please and accommodate the opposition. In 2016, the presidential palace even instructed the police to initiate legal proceedings against Ahok for blasphemy. When this proved insufficient, the regime added arbitrary criminalization of crucial Muslim and other opponents. At times, this threatened the rule of law itself. The human rights community continues to protest. Measures against corruption have also been weakened. For example, the attorney general's office has been used to target opposition party leaders and regional political executives. ${ }^{7}$

Taken together, the independence of the judiciary, the efforts at cooperation with civil society in establishing more equal citizenship and the strengthening of human rights, as well as the implementation of universal welfare policies, have been weakened. There have been tactical handouts and targeted support to Muslim communities and strongholds.

In short, the measures to contain continuation of the conflicts from 2014, and especially 2016 and 2017, were successful in facilitating peaceful elections in 2019 and securing the status quo. But several of the measures have been at the expense of civil and political liberties, programmatic politics, and the rule of law.

\section{Political Triangulation Undermining Democracy}

Jokowi's selection in August 2018 of the traditionalist Ulama Ma'ruf Amin as his vice-presidential candidate was crowning proof of the politics of accommodating one's opponents and their voters' concerns. Tactically this was of course brilliant, reducing Prabowo's ability to resume the contentious populist identity politics of 2016-2017 that had brought down Ahok and cornered Jokowi. Ma'ruf is a supreme leader in Nahdlatul Ulama and chairperson of the MUI. He was instrumental in issuing the fatwa against Ahok as well as in waging a campaign against the Muslim community

$6 \quad$ M. Mietzner, "Fighting Illiberalism with Illiberalism: Islamist Populism and Democratic Deconsolidation in Indonesia," Pacific Affairs 91, no. 2 (June 2018): 268-282.

Tom Power, "Jokowi's authoritarian turn," New Mandela, 9 October 2018, https://www. newmandala.org/jokowis-authoritarian-turn/. 
Ahmadiyah, considered to be deviant. He fostered the contentious "antipornography law" and is very much against the LGBT community. The MUI has become an increasingly important special link between state and civil society. ${ }^{8}$ Ulamas from various registered Muslim organizations are members, including extreme ones. The MUI is also widely respected by Jokowi's critics. It issues major fatwas and oversees the issuing of halal licences and the running of hajj travel-from which it is gaining additional income, on top of state funding.

As for the long-term consequences, however, it may be argued that the introduction of the MUI leader as vice-president of the country signals an important step away from Indonesia's secular administration and religious pluralism. The selection of Ma'ruf as vice-presidential candidate also clearly reduced the programmatic differences between the blocs, confirming Jokowi's retreat with regard to equal citizenship, human rights, anticorruption, and universal rather than targeted (pro-Muslim) welfare policies.

As for the crucial economic and labour market issues, the outstanding economist Sri Mulyani Indrawati retained her position as finance minister, but in the government's proposals before the elections there were no specific policies for tackling the problems of decent work conditions and unemployment, or on manufacturing and services. There was no mention of negotiations with employers and unions on these matters.

Separately Jokowi also renewed emphasis on the importance of central rule and national unity, symbolized in the Pancasila principles, ${ }^{9}$ by bringing more military leaders into his administration. General (ret.) Luhut Binsar Pandjaitan was crucial from the outset, but then, for example, Suharto's former Commander General (ret.) Wiranto, was made coordinating minister for Political, Legal and Security Affairs and General (ret.) Moeldoko was appointed chief of the president's staff.

These decisions to enroll the major Ulamas and senior military at the expense of the principles and reformist policies that had caught people's attention when Jokowi was elected in 2014 bring to mind the efforts at "politics of triangulation," pioneered by Bill Clinton in the United States and by Tony Blair and others in Europe. That is, to blend the most attractive parts of the major contenders' views while also trying to transcend them in a third direction. Blair, for one, brought neoliberal policies into the British Labour government, and claimed to combine them with policies of equality of opportunity, thus offering a "third road." In Indonesia, Jokowi seems to have tried to revive President Sukarno's way of boosting his agenda by combining the Muslim priorities of the Nahdlatul Ulama with the nationalist military leaders' coercive capacity. But Jokowi is short of Sukarno's popular

Schäfer, "Democratic Decline in Indonesia."

Currently framed as "Belief in the One and Only God; a just and civilized humanity; a unified Indonesia; democracy, led by the wisdom of the representatives of the people; social justice for all Indonesians." 
base and vision. And the prime worries are, of course, that Jokowi's compromises reduce the political choices for ordinary people, which are so essential for democracy, and that the elites and their parties form cartels. Historically, the similar reduction of people's voice was among the factors that brought down Indonesia's liberal constitutional democracy in the late 1950 s, in favour of Guided Democracy.

\section{The Revival of Socio-religious and Ethnic Politics}

As pointed out by Edward Aspinall and others, tampering with the rule of law and what I have labelled political triangulation fostered, in turn, the revival of the political geography of socio-religious pillars and patronage politics, which dominated Indonesia before Suharto's New Order. ${ }^{10}$ This would explain much of the election results. In short, Jokowi-Ma'ruf secured their heartlands in Hindu-dominated Bali, and among the ethnic Javanese in East and Central Java, together with other provinces with significant numbers of Javanese migrants and non-Muslim voters (for whom tolerance and pluralism are particularly important). Vice-presidential candidate Ma'ruf Amin's Nahdlatul Ulama (NU) was (and continues to be) particularly strong in East and also Central Java (with 61.5 percent of the 193 million voters). According to a reliable exit poll by Indikator Politik Indonesia, 95 percent of non-Muslim voters voted for Jokowi-Ma'ruf, 15 percent more than in 2014. And 56 percent of NU's grassroots members supported Jokowi-Ma'ruf, an increase of 12 percent. ${ }^{11}$ In short, Jokowi's core followers, pluralist Muslimsmany of whom belong to the less privileged classes-were combined with non-Muslim voters as well as traditionalist NU sympathizers, the latter often from among landowners and the petit bourgeoisie.

Meanwhile Prabowo-Sandiaga gained overwhelming support from the typically well-to-do and well-educated members of Muhammadiyah and other Muslim organizations with theologically modern orientations, in addition to the brotherhood PKS party, and won in the Muslim strongholds in the western parts of Java and Sumatra, and elsewhere.

This pattern resembles the political stronghold of Sukarno and his political allies in the 1950s and early 1960s, especially among Javanese and Balinese nationalists of various religious inclinations, reformist communists among pluralist-oriented Muslims in particular, and traditionalist Muslims. On the other side were the modernist Muslim and Islamist-based parties, with strong bases in western Java, Sumatra, Sulawesi, and parts of Kalimantan and Maluku,

10 Ed Aspinall, "Indonesia's Election and the Return of Ideological Competition," New Mandala, 17 April 2019, https://www.newmandala.org/indonesias-election-and-the-return-of-ideologicalcompetition.

11 Indikator Politik Indonesia https://nasional.kompas.com/read/2019/05/29/20001181/ politik-identitas-dianggap-sebagai-winning-template-di-pilpres-2019. 
and Singapore-oriented leaders like Prabowo's father, the economist Soemitro Djojohadikoesoemo, in an unholy alliance in favour of the West against Sukarno's radical nationalism.

There certainly were other factors behind Jokowi's losses in a number of the Muslim-dominated provinces. One was the reduced commodity prices in Sumatra, another the loss of votes from the supporters of outgoing vice president Jusuf Kalla in his southern Sulawesi heartlands. But two major points stand out. First, the primarily non-pluralist Muslim areas held on to their socio-religious and ethnic identity-based politics, in spite of Jokowi's infrastructural investments across the archipelago and attempts at implementing both universal and pro-Muslim welfare measures. Second, Jokowi seems to have been saved by more votes than in 2014 in the areas dominated by more pluralist Muslims.

\section{Back to Socio-religious and Ethnic Pillars, but not Liberal Democracy}

While, as I have argued, the immediate causes for the electoral outcome in terms of stability at the cost of undermining Indonesian democracy are clear, the equally important but less discussed issue is that of how this regression became possible. In a longer historical perspective, the crucial factors seem to rest with, first, the structural limits of Indonesian democratization and, second, the causes for Jokowi's retreat from his reformist agenda.

Explanations for the electoral results referring to the resurgence of the old socio-religious and ethnic pillars that dominated Indonesian politics in the 1950s tend to ignore the fact that this earlier period was also characterized by more liberal democracy and representation of economic interests and modern ideologies than has been the case in the new democracy established after the fall of Suharto. For one, most parties in the 1950s were certainly dominated by elites, but not by economic oligarchs to the extent that we see today. Second, the communists and socialist-oriented nationalists spearheaded one of the world's largest popular reformist movements, standing for equal citizenship and social rights, while there has still not been any space for a similarly oriented dimension in Indonesia after the revival of democracy in 1999.

As documented and analyzed in extensive studies of democratization based on the insights of pro-democracy actors, ${ }^{12}$ interest organizations remain weak and fragmented. The new democratic institutions were designed to accommodate those dominant groups from the Suharto era that were

12 For summaries, see A. Savirani and O. Törnquist, eds., Reclaiming the State: Overcoming Problems of Democracy in Post Soeharto Indonesia (Yogyakarta: PolGov and PCD Press, 2015); and O. Törnquist et al., "The Downside of Indonesia's Successful Liberal Democratisation and the Way Ahead. Notes from the Participatory Surveys and Case Studies 2000-2016," Journal of Current Southeast Asian Affairs 1 (2017): 123-138. 
prepared to adjust, while the pro-democracy activists and their organizations were advised by the architects of the new institutions either to join the elitist parties or engage in civil society. ${ }^{13}$ As noted by many scholars, this may have been the necessary price for the rise of the new democracy.$^{14}$ But it was not inevitable that institutions should have been designed in such a way that they prevented the rise of alternative programmatic parties with firm social roots. Local parties, for example, have been barred outside Aceh. A new party that wishes to participate in any other elections, even locally, must have a nationwide presence in terms of offices and constituents in all provinces, 75 percent of their regencies and municipalities, and 50 percent of the sub-districts in these regencies and municipalities. Existing parties are also privileged in the direct elections of political officials. Independent candidates need to prove they have large numbers of followers. Within the existing parties, too, the open list system has increased vote-buying by rich and well-connected candidates at the expense of their less fortunate party-fellows. Media, finally, is largely subordinated to commercial actors and their political partners. In brief, ever since the introduction of democracy in 1998, only already powerful and moneyed actors have stood a decent chance within organized politics.

Meanwhile, most attempts by democratic issue and interest groups to influence politics from outside by way of coalitions and joint actions have failed. This has given rise to a variety of alternative routes to influence politics by way of lobbying, horse-trading, and adjustment to established parties.

Even the dynamic Indonesian democratization of the 1950s was insufficient to withstand Sukarno's Guided Democracy (which depended upon its association with the military), followed by Suharto's New Order. There are of course important differences between the present dynamics and those that generated Guided Democracy. But the present risks of deterioration, given the recent tampering with the principles of the rule of law, negation of programmatic politics, and especially the poor representation of fundamental social and economic interests, are overwhelming.

\section{Populist Opening and Impasse}

Much of the crisis of today's seemingly stable Indonesian politics rests, therefore, with the deficiencies of post-Suharto democratization. In the designing of Indonesia's new democracy, more effort was focused on accommodating powerful actors and the quest for decentralization than at restoring the 1950s attempts at establishing equal citizenship and social rights along with representation of the major interests in society.

Between about 2005 and 2015, however, there were four promising

13 For example, W.R. Liddle, ed., Crafting Indonesian Democracy (Bandung: Mizan Pustaka), 2001.

14 E. Aspinall, "The Irony of Success," Journal of Democracy 21, no. 2 (2010): 20-34. 
openings. ${ }^{15}$ One is best illustrated by the local social contracts on urban development in Solo, Central Java. ${ }^{16}$ Jokowi, the directly elected mayor, was in need of extra-parliamentary support beyond the elitist parties in the city council. Civil society groups facilitated various organizations among the urban poor. They demanded fair compensation and alternatives for the poor, in the face of business and middle-class driven modernization of the city centre. Jokowi was convinced, and delivered. The successful Solo model even received attention internationally, especially when Jokowi was ranked third in a 2012 competition to find the best mayors in the world. The Solo achievements were the major source of inspiration when Jokowi first gained the position of governor of Jakarta and then became the president of the country.

The second opening was the equally successful broad alliance at the central level in the early 2010s, between progressive politicians, civil society, and urban poor and union activists, in favour of reforms to provide universal public health coverage. During Jokowi's and Ahok's reigns in Jakarta there were additional welfare measures put in place.

Third, over the same period, there were also attempts at social movement unionism when permanently employed workers combined with subcontracted and informally employed labourers in struggling for better employment conditions and decent minimum wages.

Fourth was the attempt by Jokowi, when elected president, to cooperate with the anti-corruption agency and civil society activists to scrutinize potential cabinet members and senior bureaucrats. This was to foster a cabinet and presidential staff based, as Jokowi had promised, on sincerity, merit, and capacity. The intent was to keep the opportunistic supporters among the political elite and business at bay.

Initially, therefore, Jokowi and his team made remarkable political advances, and the activists gained ground too. The obvious question is why did these advances prove insufficient for containing the campaign by conservative politicians and Muslims? Why did Jokowi instead accommodate his opponents, triangulate his policies, and tamper with the rule of law to block some of the most militant critics?

Researchers point to a series of obstacles. ${ }^{17}$ One is that the civil society movement in Jakarta was more fragmented and less forceful than in Solo. Activists were unable, for example, to enforce fair agreements between the urban poor and Ahok, Jokowi's successor as governor. This made it easier for the contending Muslim populists to promise better agreements.

15 For this section on populist openings and impasse, see L. Djani et al., Dilemmas of Populist Transactionalism. What are the prospects now for popular politics in Indonesia? (Yogyakarta: PolGov and PCD Press 2017), and further references therein.

16 Pratikno and C. Lay, "From Populism to Democratic Polity. Problems and Challenges in Surakarta, Indonesia," Democratisation in the Global South: The Importance of Transformative Politics, eds. K. Stokke and O. Törnquist (Basingstoke: Palgrave, 2013).

17 Djani et.al., Dilemmas of Populist Transactionalism. 
Further, the anti-corruption movement that tried to assist in screening candidates for Jokowi's first cabinet in order to foster "good governance" was challenged by powerful actors aiming at Jokowi's administration, and did not succeed in winning broad public support. This was in contrast with New Delhi in particular. As in Indonesia, the India Against Corruption campaigners focused against top-level abuse of power and tried to secure the establishment, by extra-parliamentary means, of an independent and powerful anti-corruption agency. The parliamentarians retained their independence, however, and challenged the activists to get themselves elected if they wanted to implement their ideas. In India, it was technically possible to form an alternative political party. This happened in late 2012, and the new Aam Aadmi ("Common Man") Party (AAP) won the local elections in Delhi a few months later. Most importantly: the major factor behind the success of the AAP was that in contrast to Indonesia, the focus now was not just on corruption within the elite but also on the abuse of public services, which matters most to common people. ${ }^{18}$

More fundamentally, in Indonesia there was no strategy of transformative reform. The alliance for public health reform did not sustain its work by turning to additional reforms such as for the right to decent jobs, which as a second step in a series of reforms might have fostered gradual transformation. There was no emphasis, either by Jokowi or the activists, on building democratic institutions for representation in public policy making of issue groups such as those working on anti-corruption and human rights, and interest groups such as unions and employers' associations. Hence, leaders and groups slid back into individual negotiations over special interests with the highest bidding politician. The forceful Confederation of Indonesian Trade Unions, for example, even opted for Prabowo, in 2014 and again in 2019.

In other words, aside from the weakness of the civil society movement, the prime cause of the setbacks was first, the lack of an agenda for a sequence of reforms that different groups and unions could unite around; and second, the "transactional populism" of individual horse-trading rather than democratic representation.

As a result, the progressive sections of Jokowi's team did not have much of a democratic mass-based alternative to offer in the face of the massive onslaught of rightist counterpopulism, with Muslim identity politics in the forefront.

This is, I believe, the major reason for Jokowi's opting instead for a defensive triangulation of policies, the return to the primacy of socio-religious

18 For example S. Ramani, “The Aam Aadmi Party's Win in Delhi: Dissecting It Through Geographical Information Systems," Economic and Political Weekly 2013, http://www.epw.in/webexclusives/; S. Roy, "Being the Change: The Aam Aadmi Party and the Politics of the Extraordinary in Indian Democracy," Economic and Political Weekly 49, no. 15 (2014): 45-54; S. Shukla, "Myopia, Distortions and Blind Spots in the Vision Document of AAP," Economic and Political Weekly 48, no. 7 (2013): 16-18. 
and ethnic loyalties, the accommodation of the contending actors, and the tampering with the principles of rule of law-all of which, in turn, produced the signs of shallow stability in the 2019 elections.

\section{What's Next?}

The immediate outcome of the elections is difficult to predict. Some of the parties in Prabowo's coalition-at least Yudhoyono's nationalist-religious Partai Demokrat—are likely to offer their support for Jokowi in return for particular favours. Moreover, Jokowi seems to be eager to accommodate Prabowo's Gerindra party too. Meanwhile there will be intense competition for the leading positions before the next national elections in five years' time. Prabowo might consolidate his party in favour of his business interests and chances to sponsor likeminded candidates. By 2024 Jokowi will have served his two terms, but until then he may wish to explore ways of reinventing his original project of more inclusive development. Ma'ruf Amin was only accepted as a senior leader, capable over the short term of defusing militant Muslim action, while the younger contenders, including Megawati's daughter Puan Maharani and former Constitutional Court Chief Justice and also Islamic pluralist Mahfud MD, blocked each other. They and others may now prepare for the competition over top positions. Will there be any room for alternatives?

The return of populist politics in Indonesia (after a long gap, from the days of Sukarno) was associated with the introduction of direct elections of political executives in the mid-2000s. Formerly, these executives were appointed by the local and regional parliaments; and in the elections by proportional representation to these parliaments, the parties tended to rely on clientelism and their particular socio-religious and ethnic followers. In the new direct elections of the executives, however, successful contenders have usually tried to go beyond this pattern by means of populist appeals to gain more votes. There are signs from the 2019 combined elections that the parties and candidates did not always adjust to the priorities of the coalitions for the presidential candidates. Yet, contentious populism might return to the fore in the next round of direct elections of political executives. A major question then is whether and how reformist candidates, such as Jokowi once was, can make a difference by overcoming the temptation to become managerial technocrats and instead focus on fostering social pacts and broad alliances among civil society actors and interest groups in order to bring about reforms that matter to people at large. Such reforms could include improved welfare, and decent jobs in expanding manufacturing and public services, beyond the temporary commodity boom and infrastructural projects. This would make the reformists less dependent on identity politics and transactions with powerful elites and oligarchs. There are a few such candidates out there, including the governors of West and Central Java. 
Jokowi might be able to renew his agenda and capacity in cooperation with such local and regional leaders, along with broad alliances. Renewal-oriented urban politicians like those from the new PSI party who did not make it to the national parliament, but did to a number of the local parliaments, might prove their points in similar ways.

In any case, Indonesia's democracy is dangerously weakened and there are risks that something similar to Guided Democracy might evolve into "in defence of national unity," but now with a weaker president joining hands with nationalist officers and traditionalist Muslims. In view of a longer historical perspective and results from research based on the insights of the pro-democracy activists, I have argued that the root problem, which became apparent in the 2019 elections, is that huge numbers of people have the right to vote but little voice. There are few political alternatives and poor representation, even as compared with the larger Indian democracy. The rule of law is crucial, but it takes broad popular support to enforce it. The resurgence of democracy after the fall of Suharto accommodated the powerful groups. This was unavoidable. But the rules of the game worked against chances for citizens to relate to the state through their own organizations, rather than through patrons and religious and ethnic communities. The window of change by means of reformist populism from about 2005 testified to the potential of building broad alliances behind demands for equal citizenship, universal welfare, and decent work conditions. Actual developments subsequently, however, also showed up the lack of an agenda for a series of transformative reforms, as well as the drawbacks of supposedly direct populist relations between leaders, individual groups, and imagined "people."

To alter the backsliding of Indonesia's democracy it seems necessary, therefore, to prioritize support for two processes. First, the development of strategic reform agendas that people can unite around, rather than shaping an identity to oppose others. Second, proposals for democratic representation of issue-based and interest organizations, rather than divisive transactions between populist leaders and assorted groups. Ironically, Muslim leaders of various inclinations have managed to get the support of the government and international peers to build up an immensely influential Ulama Council as a means of indirect rule of people. But the democracy-oriented issue and interest movements, as well as the president in need of their support, and the pro-democratic international community, have not yet tried to establish a similar forum for direct deliberation of public policies between state and citizens.

University of Oslo, Blindern, Norway, June 2019 